\title{
Assessing the Impact of Land-Use Planning on the Atmospheric Environment through Predicting the Spatial Variability of Airborne Pollutants
}

\author{
Longgao Chen ${ }^{1, *}$, Long $\mathrm{Li}^{2,3, *}$, Xiaoyan Yang ${ }^{1}$, Yu Zhang ${ }^{1}$, Longqian Chen ${ }^{2}$ and Xiaodong Ma ${ }^{1}$ \\ 1 School of Geography, Geomatics and Planning, Jiangsu Normal University, Xuzhou 221116, China; \\ yangxy0705@163.com (X.Y.); yuzhang@jsnu.edu.cn (Y.Z.); xiaodgma@163.com (X.M.) \\ 2 School of Environmental Science and Spatial Informatics, China University of Mining and Technology, \\ Xuzhou 221116, China; chenlq@cumt.edu.cn \\ 3 Department of Geography, Earth System Science, Vrije Universiteit Brussel, Brussels 1050, Belgium \\ * Correspondence: chenlonggao@163.com or longgao.chen@jsnu.edu.cn (L.C.); long.li@cumt.edu.cn (L.L.); \\ Tel.: +86-516-83403858 (L.C.); +86-516-83591327 (L.L.)
}

Received: 8 November 2018; Accepted: 7 January 2019; Published: 9 January 2019

\begin{abstract}
As an important contributor to pollutant emissions to the atmosphere, land use can degrade environmental quality. In order to assess the impact of land-use planning on the atmosphere, we propose a methodology combining the land-use-based emission inventories of airborne pollutants and the long-term air pollution multi-source dispersion (LAPMD) model in this study. Through a case study of the eastern Chinese city of Lianyungang, we conclude that (1) land-use-based emission inventorying is a more economical way to assess the overall pollutant emissions compared with the industry-based method, and the LAPMD model can map the spatial variability of airborne pollutant concentrations that directly reflects how the implementation of the land-use planning (LUP) scheme impacts on the atmosphere; (2) the environmental friendliness of the LUP scheme can be assessed by an overlay analysis based on the pollution concentration maps and land-use planning maps; (3) decreases in the emissions of $\mathrm{SO}_{2}$ and $\mathrm{PM}_{10}$ within Lianyungang indicate the overall positive impact of land-use planning implementation, while increases in these emissions from certain land-use types (i.e., urban residential and transportation lands) suggest the aggravation of airborne pollutants from these land parcels; and (4) the city center, where most urban population resides, and areas around key plots would be affected by high pollution concentrations. Our methodology is applicable to study areas for which meteorological data are accessible, and is, therefore, useful for decision making if land-use planning schemes specify the objects of airborne pollutant concentration.
\end{abstract}

Keywords: land-use planning; environmental impact assessment; atmospheric quality; emission inventory; airborne pollution

\section{Introduction}

Land resources are vital to support human survival and social development. In recent decades, however, they have been significantly influenced by human activities due largely to rapid demographic growth. Those activities directly related to land use include agriculture and urbanization, which have intensified changes in environmental quality on both regional and global scales [1]. Some land-use types are generally accompanied by pollutant emissions into water, soil, and the atmosphere, hence degrading the environmental quality [2,3] and even threatening human health [4-6]. Predicting the spatial variability of these airborne pollutants has, therefore, become an essential component of the assessment of the land-use impact on the environment. Land-use planning (LUP) (Table A1 in Appendix A) describes the future land-use in terms of its pattern and distribution [7] in accordance 
with regional development strategies [8], especially at a city/county level. As such, environmental impact assessment of LUP (LUPEA) should evaluate the influence of future land-use on a regional environment [9].

In order to assess the land use and land-use planning's impact on the atmospheric environment, a variety of assessment methodologies have been developed. Emission inventories prove useful for assessing atmospheric quality [10-13]. However, in general, emission inventories are mostly made for a specific industry or industrial category [14-17]. This means that the cost and time requirements for acquiring emission data are very high, particularly when emission inventories are used in strategic environmental assessment (SEA) — which has an even higher data demand. Land-use-based emission inventories, however, provide a feasible way to assess the overall pollutant emissions in a LUPEA applied to a moderate-scale geographical region (e.g., a typical Chinese city covering an area of thousands of square kilometers).

Previous studies have used land-use regression models to characterize the variability of airborne pollutants [18-22], or dispersion models to predict and assess pollutant dispersion [23-25]. As the land-use regression models are statistically based, their results are less reliable for areas with a limited number of monitoring sites to measure the concentrations of airborne pollutants. This is, however, not the case for the airborne pollutant dispersion models-which are based on the investigation of pollutants, the impacts of regional meteorology, topography, and so on.

In order to assess the impact of LUP implementation on the atmospheric environment, it is practical to use an airborne pollutant dispersion model if key factors contributing to pollution are determined. The long-term air pollution multi-source dispersion (LAPMD) model has, therefore, been developed, based on the prediction of pollutant dispersion in the reference year [26]. The assessment is expected to be improved if pollutant concentrations are calculated using pollutant inventories for the reference and individual target years.

In this study, we propose a new methodology combing land-use-based emission inventory and LAPMD model for assessing LUP impact on the atmospheric environment. The specific objectives of this study are (1) to establish a land-use-based emission inventory to support the assessment of the LUP impact on the atmosphere; (2) to develop a method for assessing the LUP impact on the atmospheric environment by combining a land-use-based emission inventory and the LAPMD model; and (3) to demonstrate the application of the methodology through a case study of Lianyungang, an eastern Chinese city in Jiangsu province.

\section{Materials and Methods}

An emission inventory of airborne pollutants can provide spatial source intensity for dispersion assessment. Emissions from individual land-use types in the reference and target years can be estimated using their respective inventories. By means of the LAPMD model, spatial variability of airborne pollutants in the reference and target years can be quantified, and the LUP impact on the atmospheric environment can be assessed. Figure 1 illustrates the procedure for our proposed assessment of LUP impact on the atmospheric environment. 


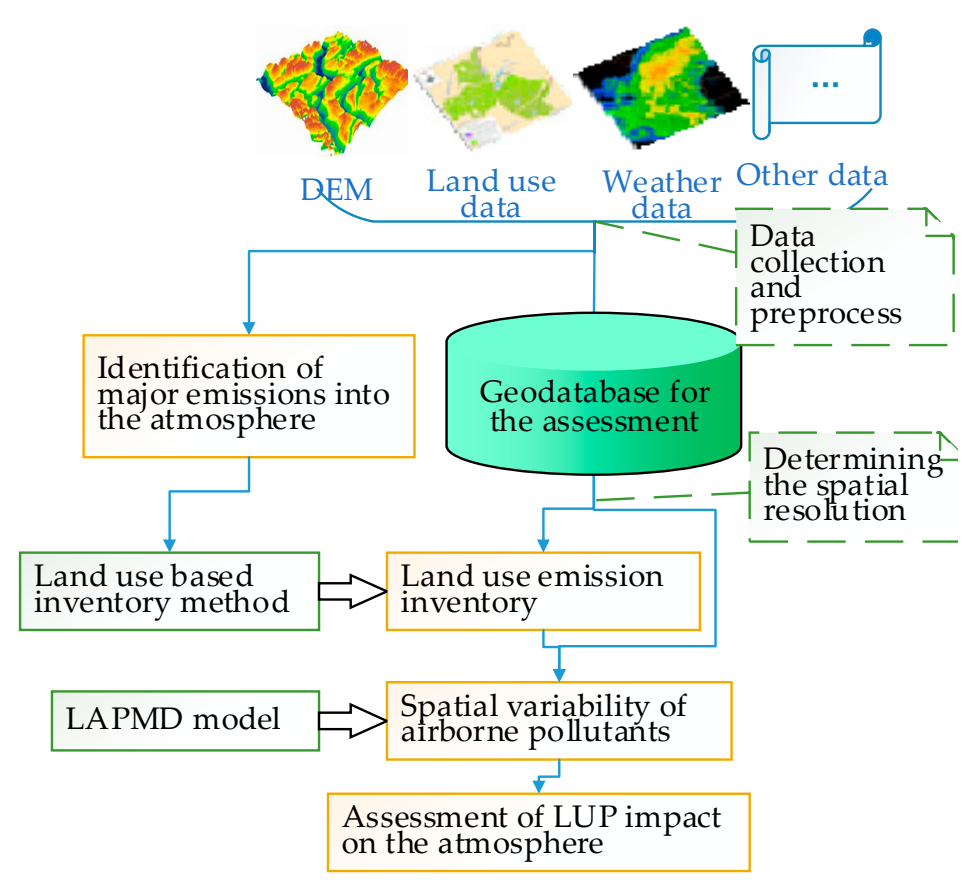

Figure 1. Flowchart for the land-use planning (LUP) atmospheric environment impact assessment.

\subsection{Compiling the Land-Use-Based Air Emissions Inventory}

As emissions of airborne pollutants are closely associated with land use $[27,28]$, we compiled an emission inventory based on land use. Since the assessment of regional LUP impact on the atmospheric environment serves the needs of making macro-level decisions, the precise locations of such emissions are considered unnecessary. It is acceptable to use coarse-resolution data (i.e., raster data with a large cell size), e.g., DEM or land-use data at hundreds of meters, for the environmental impact assessment of a large administrative region, e.g., a city or county in China which often covers a geographical area of thousands of square kilometers.

Based on the land-use type, emission sources can be classified as three types, namely point, line, and area. For a city/county level LUP environmental assessment, point sources refer mainly to key plots for primary plants, line sources mostly include roads or rivers used for shipping, and area sources are residential land for both urban and rural populations. Because straw burning has been a widespread occurrence across China, particularly since the 2000s [29,30], agricultural land should be considered as a significantly important area source for assessing the land-use impact on the atmosphere.

Given the possibility and efficiency of data acquisition, we used the mass balance and emission factor-based methods [31-34] to obtain a land-use-based emission inventory. The mass balance method is based on the principle of mass conservation and thereby facilitates a 'cradle-to-emissions' approach [35]. The emission intensity of $\mathrm{SO}_{2}$ from land use can be obtained using Formula 1 according to the principle of the mass balance-based method:

$$
E=\frac{M_{\mathrm{SO}_{2}}}{M_{\mathrm{S}}} \times S \times \omega \times \varepsilon \times\left(1-\eta_{\mathrm{SO}_{2}}\right) \times 10^{3}
$$

where $E$ is the emission intensity of $\mathrm{SO}_{2}$ (unit: $\mathrm{kg}$ ), $\mathrm{MSO}_{2}$ the molecular weight of $\mathrm{SO}_{2}$ equaling $64, M_{\mathrm{S}}$ the molecular weight of sulfur equaling $32, S$ the rate of sulfur content in fuel, $\omega$ the fuel consumption (unit: ton), $\eta_{\mathrm{SO}_{2}}$ the desulfurization rate, and $\varepsilon$ the conversion rate of sulfur in fuel.

The emission factor-based method calculates the emissions based on the average emission rate from a particular activity generating emissions [36]. For example, the emission intensity from transportation land is given by Formula 2: 


$$
E_{i}=\sum P_{j} \times M_{j} \times E F_{i, j} \times 10^{-3}
$$

where $E_{i}$ is the emission intensity of pollutant $i$ (unit: $\mathrm{kg}$ ), $P_{j}$ the holding quantity of vehicle $j, M_{j}$ the annual average running mileage of vehicle $j$ (unit: $\mathrm{km} /$ per vehicle), $E F_{i, j}$ the emission factor of pollutant $i$ from vehicle $j$ (unit: $\mathrm{g} / \mathrm{km} \cdot$ per vehicle).

After estimating the emission intensity, the spatial distribution of pollutant emissions for each year can be mapped in ArcGIS (Esri, Redlands, CA, USA), by assigning average emissions for individual land-use types (i.e., total emission intensity of pollutants for a land-use type divided by the number of raster cells for the land-use type) to their respective raster cells.

\subsection{Calculating the Annual Airborne Pollutant Concentration}

The LAPMD model was used in this study to calculate the long-term land-use airborne pollutant multi-source concentration. This model can predict the annual dispersion of airborne pollutants based on a Gaussian dispersion model [26]. For the long-term dispersion of airborne pollutants, this model assumes that (1) the wind direction is divided into eight categories, each having a range of $45^{\circ}$, its frequency is equal for each fan-shaped area, and the pollutants are in the area and meet the regulation of Gaussian dispersion and (2) the source height value is the weighted average of different pollutant sources' heights (the source height is the sum of the height of a pollutant source in relation to the ground surface and the height of the pollutant source's bottom in relation to sea level, e.g., the source height for a 30-m-high chimney at $200 \mathrm{~m}$ above sea level is $230 \mathrm{~m}$ ). Therefore, the LAPMD model can be described by the following equations:

$$
\begin{gathered}
\int_{\alpha_{1}}^{\alpha_{2}} c(x, y) d_{y}=\frac{Q}{\sqrt{2 \pi} \bar{u} \sigma_{y} \sigma_{z}} \exp \left(-\frac{\Delta H+H}{2 \sigma_{z}^{2}}\right) T \\
c(x, y)=\left(\left(\frac{Q}{\sqrt{2 \pi} \bar{u} \sigma_{y} \sigma_{z}} \exp \left(-\frac{\Delta H+H}{2 \sigma_{z}^{2}}\right)\right) / \frac{\pi x\left(\alpha_{2}-\alpha_{1}\right)}{180}\right) T \\
\int_{0}^{\infty} \int_{\alpha_{1}}^{\alpha_{2}} c(x, y) d_{y} d_{x}=Q
\end{gathered}
$$

where $c(x, y)$ is the near ground average concentration of airborne pollutant in the grid with the position $(x, y)$ in the fan-shaped area with the center of pollution source and angle from $\alpha_{2}$ to $\alpha_{1}, \sigma_{z}$ is the vertical dispersion parameter, $\sigma_{y}$ is the dispersion parameter of the grid with distance $y$ from the source, $Q$ is the source intensity of the pollutant in the grid, $T$ is the attenuation parameter of pollutant, $\Delta H$ is the height of the pollutant source in relation to the ground surface (e.g., the height of a chimney), and $H$ is the height of the pollutant source's bottom in relation to sea level. A detailed description of the LAPMD model and the methods to extract the parameters can be found in our previous study [26]. In the methodology, the source intensity characterizes the land-use emission obtained in the inventory. All the spatial data are re-sampled to have an equal cell size for spatial analysis and calculation. After inventorying land-use emissions, parameters including the height of the pollutant source, elevation of the emission source, wind speed in each direction, dispersion parameters were put into the Matlab function of the LAPMD model. Then the annual land-use emission concentration maps at the same resolution will be obtained and imported into the geodatabase.

\subsection{Assessing the LUP Impact on the Atmosphere}

Long-term land-use airborne pollutant multi-source concentrations, which directly reflect the land-use impact on the atmospheric environment, were calculated using the LAPMD model for the reference and target years, respectively. The impact assessment can be performed by the spatial comparison of the airborne pollutant dispersion results between the reference and target years. 
In addition, the environmental friendliness of the land-use planning scheme can be evaluated through the overlay analysis of the land-use planning map with the concentrations map.

\section{Case Study: Lianyungang, Eastern China}

\subsection{Study Area and Data}

To demonstrate the application of the proposed methodology, the land-use planning scheme of Lianyungang (2010-2020) was used to assess its LUP impact on the atmosphere for the reference year (2010) and target year (2020). As a coastal city in Jiangsu province in Eastern China (Figure 2), Lianyungang is characterized by a temperate monsoon climate with an annual precipitation of $920 \mathrm{~mm}$ and an average temperature of $26.5^{\circ} \mathrm{C}$ in summer and of $-0.4{ }^{\circ} \mathrm{C}$ in winter. Land-use types in this city include cropland, forest, water, transportation, commercial land, industrial, residential land, and typical coastal land-use classes such as tideland and saltern. A population of more than 4 million have led to drastic land use/cover changes in the region, especially since the 1980s. This has triggered considerable environmental challenges including atmospheric pollution.
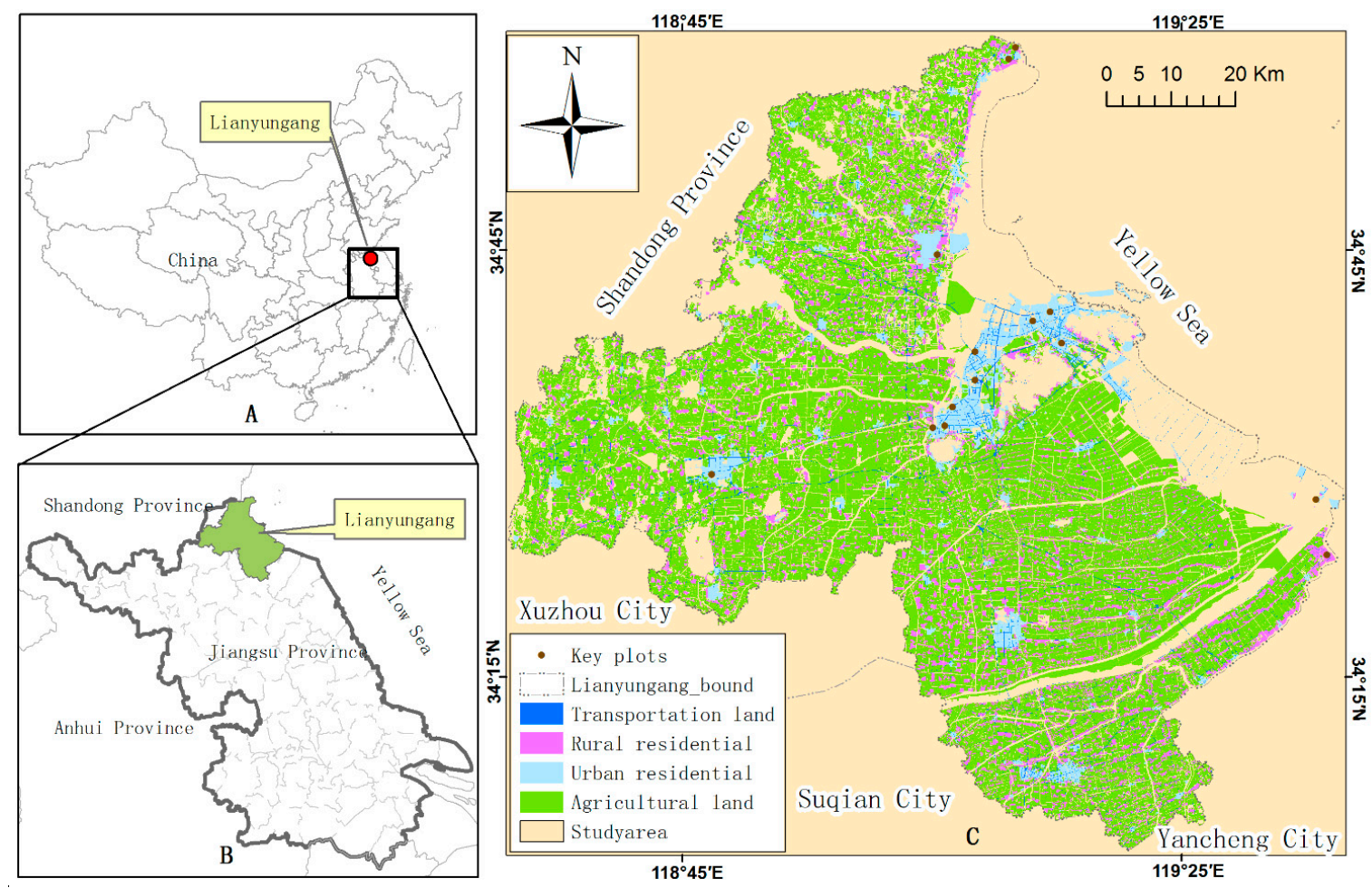

Figure 2. The location of Lianyungang (A,B) and its land-use map of 2010 (C). This map highlights the major land-use types and key plots emitting airborne pollutants in the study area.

To predict the spatial variability of airborne pollutants and assess LUP impact on the atmospheric environment, the study area was limited to the entire geographical area of Lianyungang (i.e., both its urban and rural areas) and its adjacent areas (indicated in beige color in Figure 2). Spatial data used in the study include an improved 30-m ASTER GDEM (Advanced Spaceborne Thermal Emission and Reflection Radiometer Global Digital Elevation Model) dataset [37] as the ground height of the pollutant source, a land-use database of 2010, and the land-use planning scheme of Lianyungang for 2010-2020 obtained from local land management authorities. Daily meteorological data of 2010 (e.g., cloud cover, wind directions, and wind speeds) were freely available from the China Meteorological Data Sharing Service System. Data such as emissions of $\mathrm{SO}_{2}$ and $\mathrm{PM}_{10}$, attenuation parameter of pollutants, and pollutant source height (i.e., chimney height) were collected from local environmental 
authorities. Note that the pollutant source height is the sum of the ground height of the pollutant source and the chimney height.

\subsection{Land-Use-Based Emission Inventory of Airborne Pollutants}

\subsubsection{Classifying the Emission Sources}

Despite a wide range of emissions from land use into the atmosphere in Lianyungang, only primary pollutants that profoundly reduce environmental quality and human health are a primary concern to the public. As many industries in China continue to rely on the consumption of fossil fuels, particularly coal, due to the high cost of upgrading energy consumption, burning coal inevitably brings about emissions of particle matter (PM) and $\mathrm{SO}_{2}$, affecting the daily life of the regional residents. Given this fact, as well as consultancy from environmental experts, our assessment was focused on $\mathrm{PM}$ and $\mathrm{SO}_{2}$.

$\mathrm{PM}_{2.5}$ emission has been widely considered as severe pollution in China, with the most serious effects in metropolises like Beijing [38] and Shanghai [39]. However, $\mathrm{PM}_{2.5}$ monitoring sites are sparse, and were even more so in the past [40]. In China, $\mathrm{PM}_{2.5}$ emission in all city-level administrative regions has been required to be monitored and published only since 2015 [41] — there was no $\mathrm{PM}_{2.5}$ data available in Lianyungang in 2010. Despite this, to some extent, the emissions of $\mathrm{PM}_{10}$ and $\mathrm{SO}_{2}$ which reflect that of $\mathrm{PM}_{2.5}$ [42], have been regularly presented in Lianyungang's annual reports of environmental quality. Therefore, $\mathrm{PM}_{10}$ and $\mathrm{SO}_{2}$ were selected as significant airborne pollutants in the emission inventory for our assessment.

As mentioned in Section 2.1, key industrial plots with high emissions were classified as point sources, land used for vehicles as line sources, and residential and agricultural land as area sources, in our case study of Lianyungang. Locations of these land parcels were used to create features representing the pollutant sources in a GIS. All the features were imported into the assessment geodatabase and converted into raster data at 300-m resolution. Such a resolution was determined due to the trade-off between data accuracy and computing efficiency and also due to the nature of a strategic impact assessment.

\subsubsection{Inventorying the Land-Use-Based Emissions}

The mass balance method was used to estimate the emission of $\mathrm{SO}_{2}$ from the point sources of key plots and the area sources of urban residential land (Formula 1) [43] except for the rural residential land where crop residues are largely burned for cooking. The conversion rate of sulfur in fuel was assigned as $80 \%$ for coal and as $100 \%$ for oil. The average desulfurization rate $\eta_{\mathrm{SO}_{2}}$ of industrial plots were calculated using the coal consumption and $\mathrm{SO}_{2}$ emission data of some plants that we investigated. The $\eta_{\mathrm{SO}_{2}}$ for area sources like urban residential land was assigned as 0 because no facilities were in place to reduce sulfur.

An emission inventory of $\mathrm{PM}_{10}$ from the point sources of key plots and the area sources of urban and rural residential land were built using the emission factor-based method. The emission factor value of point sources was assigned as the average rate derived based on the coal consumption and $\mathrm{PM}_{10}$ emission data of the investigated plants. The emission factor values of urban and rural residential land were derived from Kong et al. (2014) [31] (Table 1). Crop residues combustion in agricultural land produces various airborne pollutants including $\mathrm{SO}_{2}$ and $\mathrm{PM}_{10}$. The emission inventories of $\mathrm{SO}_{2}$ and $\mathrm{PM}_{10}$ from agricultural land were based on the agricultural crop residues combustion and emission factor values of $\mathrm{SO}_{2}$ and $\mathrm{PM}_{10}$ reported by Zhu et al. (2012) [32] (Table 1).

Airborne pollutants from line sources were produced mainly by vehicles running on the road, either locally registered or coming from outside Lianyungang. Due to the absence of knowledge of the border-crossing vehicles in the city, we constrained the calculation of emissions to the locally registered vehicles. On the other hand, emissions from external vehicles may compensate those from local cars running out of the city to some extent. The annual average running mileage $M_{j}$ of a vehicle and the emission factor of the pollutant from a vehicle $E F_{i, j}$ were obtained from He et al., [33] and from Cai and Xie [34] respectively (Table 2). 
Table 1. Emission inventories of $\mathrm{SO}_{2}$ and $\mathrm{PM}_{10}$ from land-use point and area sources in Lianyungang.

\begin{tabular}{|c|c|c|c|c|c|c|c|c|}
\hline \multirow{2}{*}{ Year } & \multirow{2}{*}{$\begin{array}{c}\text { Emission Source } \\
\text { Types }\end{array}$} & \multirow{2}{*}{$\begin{array}{c}\text { Emission Factor of } \\
\mathrm{SO}_{2}(\mathrm{~kg} / \text { ton })\end{array}$} & \multicolumn{2}{|c|}{ Emission of $\mathrm{SO}_{2}$} & \multirow{2}{*}{$\begin{array}{c}\text { DesulfuriZation } \\
\text { Rate }\end{array}$} & \multirow{2}{*}{$\begin{array}{c}\text { Emission Factor of } \\
\mathrm{PM}_{10}(\mathrm{~kg} / \text { ton})\end{array}$} & \multicolumn{2}{|c|}{ Emission of $\mathbf{P M}_{10}$} \\
\hline & & & (ton) & $(\%)$ & & & (ton) & $(\%)$ \\
\hline \multirow{5}{*}{2010} & Key plot & - & $26,036.38$ & 74.1 & 0.6 & 2.97 & 5864.63 & 23.21 \\
\hline & Urban residential & - & 8026.77 & 22.85 & 0 & 0.15 & 42.81 & 0.17 \\
\hline & Rural residential & 0.4 & 478.5 & 1.36 & - & 3.74 & 4476.55 & 17.72 \\
\hline & Agricultural land & 0.4 & 593.8 & 1.69 & - & 10 & 14,884 & 58.9 \\
\hline & Total & & $35,135.45$ & 100 & & & $25,267.99$ & 100 \\
\hline \multirow{5}{*}{2020} & Key plot & - & $17,746.32$ & 63.82 & 0.6 & 2.97 & 3997.31 & 41.42 \\
\hline & Urban residential & - & 9565.23 & 34.4 & 0 & 0.15 & 51.02 & 0.53 \\
\hline & Rural residential & 0.4 & 430.65 & 1.55 & - & 3.74 & 4028.9 & 41.74 \\
\hline & Agricultural land & 0.4 & 62.8 & 0.23 & - & 10 & 1574.25 & 16.31 \\
\hline & Total & & 27,805 & 100 & & & 9651.48 & 100 \\
\hline
\end{tabular}




\subsubsection{Predicting the Emission Inventory Based on Land-Use Planning}

Since a LUP scheme determines the future layout and arrangement of land parcels for a region [44], it helps to build emission inventories for years to come. In the LUP scheme of Lianyungang, a number of control and protection measures have been proposed to protect its environment. The factor values required in the inventory can be determined in light of the development of environmental protection technology and social economy, and the above-mentioned control and protection measures. To make the comparison easy to understand, the target year was assigned the same factor values as the reference year.

The emission in the target year was estimated in the same way as the reference year. We calculated the fuel consumption of key plots based on the estimated production-to-utilization ratio of fuel in the target year, the area of urban \& rural residential land and the population in the corresponding areas, and the quantity of emission per capita in the reference year. We estimated the quantity of crop residue combustion based on the area of agricultural land, the quantity of emission per $\mathrm{hm}^{2}$ in the reference year, and the control of combustion in the target year, and estimated the fuel consumption of transportation land based on the estimation of holding vehicles and the pollutant emission standards of vehicles in the target year. Other factor values used in the target year considered in the inventory, such as the sulfur content rate of coal, the sulfur conversion rate of coal, and the annual average running mileage of individual vehicle types, were also the factor values in the reference year. Similarly, the emission inventory in the target year was obtained based on the layout of individual land-use types including transportation land, urban and rural residential, agricultural land, and key plots for primary plants.

\subsection{Calculating the Annual Airborne Pollutant Concentration}

The annual spatial variability of airborne pollutants was mapped through the LAPMD model. The meteorology of the study area was investigated and used to calculate the parameters including $\sigma_{z}, \sigma_{y}$, and $T$. The wind was divided into eight directions, and the wind speed in each direction was calculated by averaging daily wind speeds in that direction in 2010. The average cloud amount and solar elevation angle in each wind direction were calculated based on the daily meteorological data and used to assess the dispersion parameters $\sigma_{z}$ and $\sigma_{y}$. Given the frequency of the wind direction, the source intensity was divided into eight parts. $\Delta H$ of urban and rural residential land was assigned as the average half height of the buildings respectively, $\Delta H$ of agricultural land as $0 \mathrm{~m}$, and $\Delta H$ of key plots as the height of the chimney. $H$ is the elevation of the pollutant source provided by ASTER GDEM data.

To execute the LAPMD model, the ASTER GDEM, the source intensity, and the height of the pollutant source were converted into a matrix and imported into Matlab 7.0 platform. A Matlab code representing the model was executed to obtain the matrix of airborne pollutant concentration of the study area which was later converted into raster data and imported into the geodatabase.

\subsection{Assessing the LUP Impact on the Atmosphere}

The long-term airborne pollutant concentration in the target year demonstrates the impact of LUP on the atmospheric environment. For better comparison, the concentration was classified into three levels according to the Ambient Air Quality Standard in China (GB 3095-2012) (AQSC) [45]. The environmental friendliness of the LUP scheme was assessed by an overlay analysis of the concentration maps and the LUP scheme. Then the area of individual land-use type scheme in the target year located at different concentration levels and the impact scopes of LUP on the atmospheric environment according to different levels were obtained. 
Table 2. Atmospheric emission inventory of vehicle-based transportation land sources in Lianyungang.

\begin{tabular}{|c|c|c|c|c|c|c|c|}
\hline \multirow{2}{*}{ Year } & \multirow{2}{*}{ Vehicle Types } & \multirow{2}{*}{$\begin{array}{l}\text { Emission Factor } \\
\text { of } \mathrm{SO}_{2}(\mathrm{~kg} / \mathrm{ton})\end{array}$} & \multicolumn{2}{|c|}{ Emission of $\mathrm{SO}_{2}$} & \multirow{2}{*}{$\begin{array}{l}\text { Emission Factor } \\
\text { of } \mathrm{PM}_{10} \text { (kg/ton) }\end{array}$} & \multicolumn{2}{|c|}{ Emission of $\mathrm{PM}_{10}$} \\
\hline & & & (ton) & $(\%)$ & & (ton) & $(\%)$ \\
\hline \multirow{12}{*}{2010} & 1. passenger vehicle & & & & & & \\
\hline & Large vehicle & 0.05 & 786.52 & 5.08 & 0.02 & 314.61 & 3.57 \\
\hline & Medium vehicle & 0.01 & 153.69 & 0.99 & 0.02 & 307.37 & 3.49 \\
\hline & Small car & 0.01 & 2118.24 & 13.68 & 0.02 & 4236.48 & 48.11 \\
\hline & Mini vehicle & 0.01 & 98.59 & 0.64 & 0.02 & 197.19 & 2.24 \\
\hline & 2. truck & & & & & & \\
\hline & Heavy truck & 0.10 & 8918.00 & 57.61 & 0.02 & 1783.60 & 20.26 \\
\hline & Medium truck & 0.05 & 1305.68 & 8.43 & 0.02 & 522.27 & 5.93 \\
\hline & Light truck & 0.01 & 375.40 & 2.43 & 0.02 & 750.80 & 8.53 \\
\hline & Mini truck & 0.01 & 2.18 & 0.01 & 0.02 & 4.36 & 0.05 \\
\hline & 3. tricar & 0.05 & 1721.37 & 11.12 & 0.02 & 688.55 & 7.82 \\
\hline & Total & & $15,479.67$ & 100 & 0.02 & 8805.24 & 100 \\
\hline \multirow{12}{*}{2020} & 1. passenger vehicle & & & & & & \\
\hline & Large vehicle & 0.030 & 490.79 & 4.29 & 0.012 & 196.32 & 2.16 \\
\hline & Medium vehicle & 0.006 & 95.90 & 0.84 & 0.012 & 191.80 & 2.12 \\
\hline & Small car & 0.006 & 3029.09 & 26.46 & 0.012 & 6058.17 & 66.81 \\
\hline & Mini vehicle & 0.006 & 140.99 & 1.23 & 0.012 & 281.98 & 3.11 \\
\hline & 2. truck & & & & & & \\
\hline & Heavy truck & 0.060 & 5564.83 & 48.62 & 0.012 & 1112.97 & 12.27 \\
\hline & Medium truck & 0.030 & 814.74 & 7.12 & 0.012 & 325.90 & 3.59 \\
\hline & Light truck & 0.006 & 234.25 & 2.05 & 0.012 & 468.50 & 5.17 \\
\hline & Mini truck & 0.006 & 1.36 & 0.01 & 0.012 & 2.72 & 0.03 \\
\hline & 3. tricar & 0.030 & 1074.13 & 9.38 & 0.012 & 429.65 & 4.74 \\
\hline & Total & & $11,446.08$ & 100 & 0.012 & 9068.01 & 100 \\
\hline
\end{tabular}

Note: Vehicles are classified in light of the 2011 statistical yearbook of Lianyungang [46]. 


\section{Results}

The land-use-based emissions of Lianyungang in the reference year of 2010 and the target year of 2020 are presented in Tables 1 and 2. Table 1 shows that significant changes in emissions from land-use point sources (key plots for primary plants) and area sources (urban and rural residential land and agricultural land) from 2010 to 2020. Despite increasing emissions of $\mathrm{SO}_{2}$ and $\mathrm{PM}_{10}$ from urban residential land, all the other point and area sources in Lianyungang would expect declining emissions. In total, both $\mathrm{SO}_{2}$ and $\mathrm{PM}_{10}$ emissions would decrease remarkably over the ten years. The $\mathrm{SO}_{2}$ emissions from transportation land (Table 2) are expected to decline as well. However, $\mathrm{PM}_{10}$ emissions show a slight rise from 2010 to 2020. In terms of individual vehicle types, only small cars and mini vehicles would produce increasing emissions of $\mathrm{SO}_{2}$ and $\mathrm{PM}_{10}$.

To build the geodatabase for estimating the concentrations of land-use-based emissions, the source intensities of $\mathrm{SO}_{2}$ and $\mathrm{PM}_{10}$ in 2010 and 2020 were mapped at $300 \mathrm{~m}$ resolution (Figure 3). Major emissions from key plots, located in the northern central part of Lianyungang, are labeled in Figure 3.

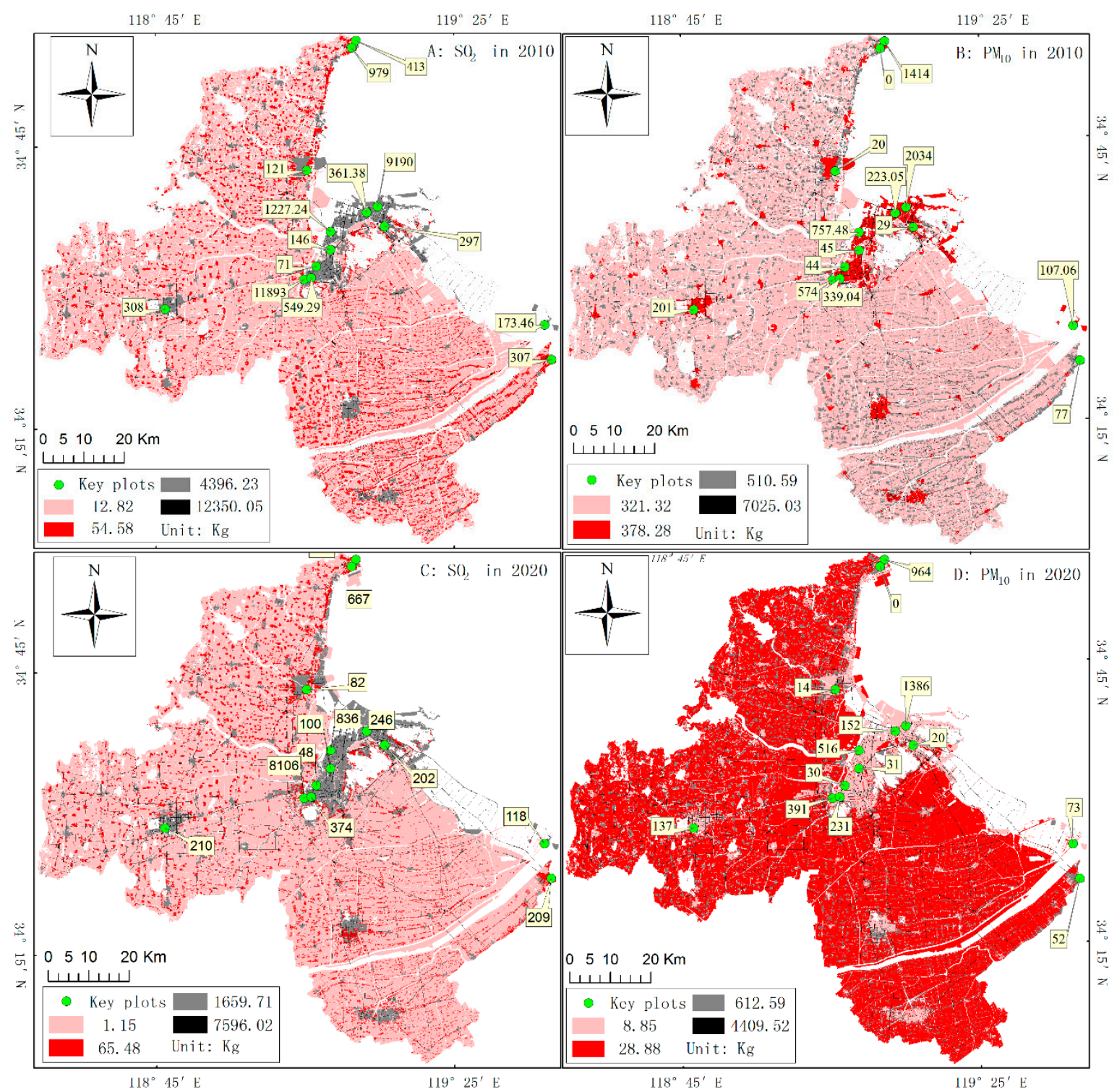

Figure 3. The source intensities of $\mathrm{SO}_{2}$ and $\mathrm{PM}_{10}$ in Lianyungang in 2010 and 2020: (A) and (C) are the concentrations of $\mathrm{SO}_{2}$ in 2010 and 2020, respectively; and (B) and (D) are the concentrations of $\mathrm{PM}_{10}$ in 2010 and 2020, respectively. The labels in the figures are the source intensity for key plots (unit: ton). 
The spatial concentrations of $\mathrm{SO}_{2}$ and $\mathrm{PM}_{10}$ were mapped for 2010 and 2020 and classified into six levels of pollution (Figure 4). It is clear that the concentrations of $\mathrm{SO}_{2}$ and $\mathrm{PM}_{10}$ with high values $\left(>0.005 \mathrm{mg} / \mathrm{m}^{3}\right)$ are basically distributed in the city center and around key plots both in 2010 and 2020 . There is a decrease in the average concentration of $\mathrm{SO}_{2}$ from 0.97 to $0.48 \mathrm{mg} / \mathrm{m}^{3}$ and of $\mathrm{PM}_{10}$ from 1.68 to $1.15 \times 10^{-3} \mathrm{mg} / \mathrm{m}^{3}$ (Table 3). Notably, the areas of highest $\mathrm{SO}_{2}$ and $\mathrm{PM}_{10}$ concentration levels would decrease from 2010 to 2020.

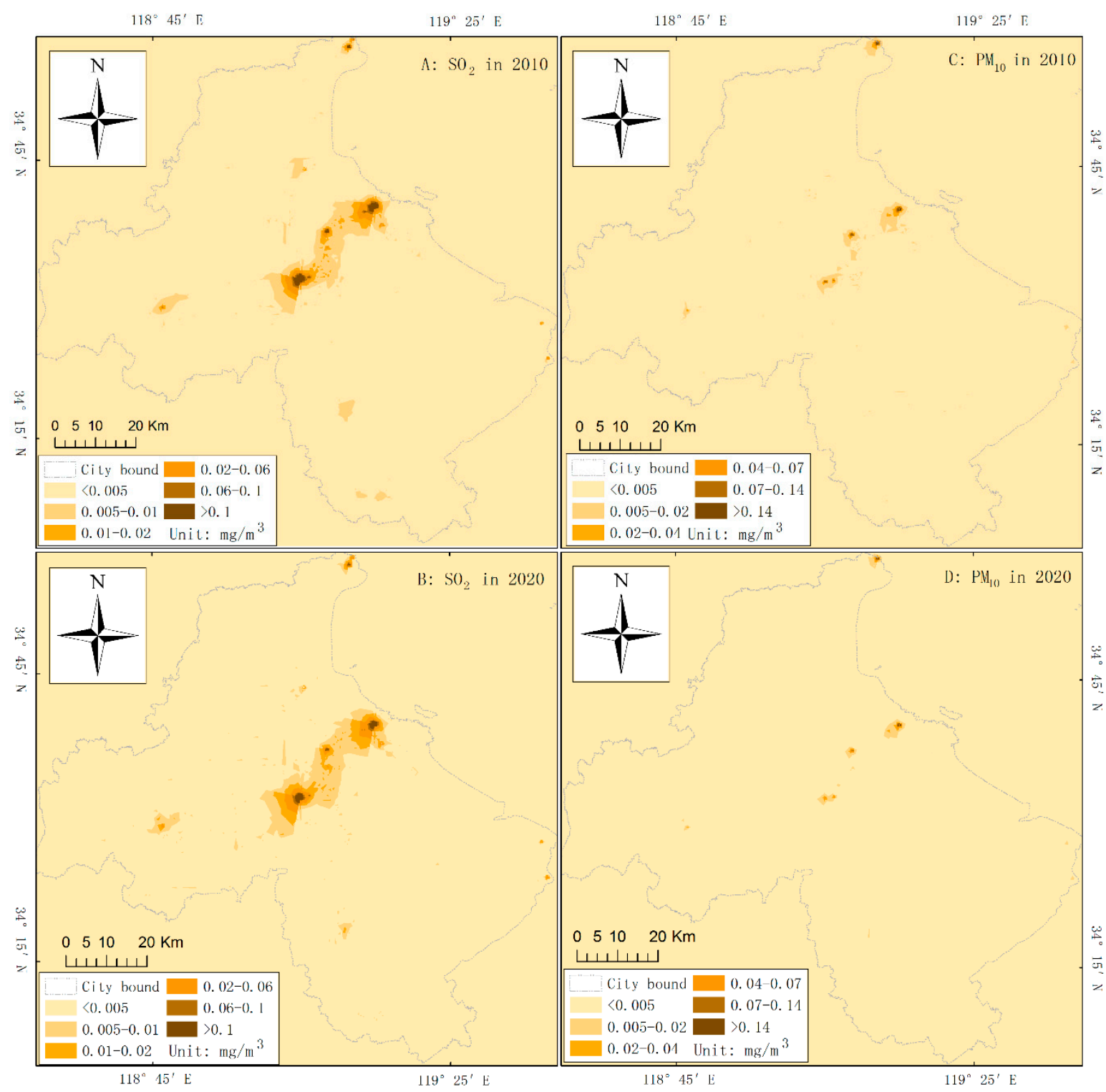

Figure 4. Classification maps of the $\mathrm{SO}_{2}$ and $\mathrm{PM}_{10}$ concentrations of Lianyungang in 2010 and 2020.

Table 3. Areas of $\mathrm{SO}_{2}$ and $\mathrm{PM}_{10}$ concentrations at different levels in 2010 and 2020.

\begin{tabular}{|c|c|c|c|c|c|c|c|c|c|}
\hline \multirow{3}{*}{$\begin{array}{c}\text { Value (Unit: } \mathbf{m g} / \mathbf{m}^{3} \text { ) } \\
<0.005\end{array}$} & \multicolumn{4}{|c|}{ Area } & \multirow{3}{*}{$\begin{array}{c}\begin{array}{c}\text { Value (Unit: } \\
\text { mg/m }\end{array} \text { ) } \\
<0.005\end{array}$} & \multicolumn{4}{|c|}{ Area } \\
\hline & \multicolumn{2}{|c|}{$\mathrm{PM}_{10}$ in 2010} & \multicolumn{2}{|c|}{$\mathrm{PM}_{10}$ in 2020} & & \multicolumn{2}{|c|}{$\mathrm{SO}_{2}$ in 2010} & \multicolumn{2}{|c|}{$\mathrm{SO}_{2}$ in 2020} \\
\hline & $16,630.5$ & $99.48 \%$ & $16,678.51$ & $99.77 \%$ & & $16,341.66$ & $97.75 \%$ & $16,301.61$ & $97.51 \%$ \\
\hline $0.005-0.02$ & 73.52 & $0.44 \%$ & 30.89 & $0.18 \%$ & $0.005-0.01$ & 270.61 & $1.62 \%$ & 282.57 & $1.69 \%$ \\
\hline $0.02-0.04$ & 7.12 & $0.04 \%$ & 4.05 & $0.02 \%$ & $0.01-0.02$ & 51.78 & $0.31 \%$ & 84.54 & $0.51 \%$ \\
\hline $0.04-0.07$ & 2.82 & $0.02 \%$ & 2.16 & $0.01 \%$ & $0.02-0.06$ & 34.79 & $0.21 \%$ & 35.76 & $0.21 \%$ \\
\hline $0.07-0.14$ & 1.92 & $0.01 \%$ & 0.9 & $0.01 \%$ & $0.06-0.1$ & 6.74 & $0.04 \%$ & 5.51 & $0.03 \%$ \\
\hline$>0.14$ & 1.17 & $0.01 \%$ & 0.54 & $0.00 \%$ & $>0.1$ & 11.48 & $0.07 \%$ & 7.05 & $0.04 \%$ \\
\hline $\begin{array}{c}\text { Average value } \\
\text { (Unit: } 10^{-3} \mathrm{mg} / \mathrm{m}^{3} \text { ) }\end{array}$ & 0.97 & & 0.48 & & & 1.68 & & 1.15 & \\
\hline
\end{tabular}




\section{Discussion}

\subsection{Land-Use-Based Atmospheric Emission Inventories}

Studies on the land-use impact on the atmosphere reveal growing concerns about decreasing environmental quality which may threaten public health [47-50]. Among a variety of airborne pollutants [51], $\mathrm{SO}_{2}, \mathrm{NOx}, \mathrm{PM}_{10}$, and $\mathrm{PM}_{2.5}$ were mostly investigated [11,52] since they are considered closely related to regional air quality [53]. In Asian countries, particularly in China and India, fine particles are a serious health threat. We understand that it would be important to consider $\mathrm{PM}_{2.5}$ for assessing the LUP impact on the atmosphere. However, we included $\mathrm{PM}_{10}$, rather than $\mathrm{PM}_{2.5}$ mainly due to the absence of the monitoring data of $\mathrm{PM}_{2.5}$ in 2010. In a LUPEA for a strategic purpose, the assessment should focus on the significant concerns with low cost and use indicators that are directly or easily available for a practicable purpose. In addition, previous studies have reported a high correlation between $\mathrm{PM}_{10}$ and $\mathrm{PM}_{2.5}$ emissions in China and beyond [54-56]. It is also reported that the contribution of $\mathrm{PM}_{2.5}$ to $\mathrm{PM}_{10}$ in the Central Black Sea in summer was 54\% [57]. As such, to some extent, the estimation of $\mathrm{PM}_{10}$ reveals the concentration of $\mathrm{PM}_{2.5}$. These studies, on the other hand, provide an alternative method for estimating $\mathrm{PM}_{2.5}$ concentration based on $\mathrm{PM}_{10}$ data when $\mathrm{PM}_{2.5}$ is not regularly monitored.

In the emission inventories of Lianyungang in 2010 and 2020, data used in the assessment (e.g., land-use and land-use planning maps, annual socioeconomic statistical data, environmental quality reports) are usually quite accessible - this allows the methodology presented to be easily applied to other study areas, particularly those with restricted data acquisition. Equally importantly, a high spatial resolution is not required for an atmospheric assessment of a region covering thousands of square kilometers.

According to Tables 1 and 2, the decreases in $\mathrm{SO}_{2}$ and $\mathrm{PM}_{10}$ emissions from point sources from 2010 to 2020 illustrates the improvement of atmospheric quality based on the land-use planning for ten years. The significant decline in emissions from agricultural land might be attributed to the implementation of the no-straw-burning policy in China from 2010. The minimum utilization rate is estimated at $90 \%$ as the goal of Lianyungang in 2020 by the government of Lianyungang. The contrasting trends in $\mathrm{SO}_{2}$ and $\mathrm{PM}_{10}$ emissions from urban and rural residential lands over the 10 years (Table 1 ) can be explained by China's rapid urbanization and economic development. A decrease in the rural population, as well as the area of rural residential land, predicted in the land-use planning scheme, would suggest lower $\mathrm{SO}_{2}$ and $\mathrm{PM}_{10}$ emissions from rural residential land in 2020 than in 2010. However, urban expansion would increase the emission of airborne pollutants including $\mathrm{SO}_{2}$ and $\mathrm{PM}_{10}$ during the 10 years-due to the daily activity of urban residents, such as heating and cooking.

The emission inventories for transportation land demonstrate how transportation land impacts the atmosphere (Table 2). In China, the quality of diesel and gasoline for vehicles has gradually been improved and car exhaust has therefore decreased. The emission factor in the target year (2020) was then estimated at $\sim 60 \%$ of that in 2010 based on the regional upgrade regulation, the application of the corresponding laws and rules in China, and a Chinese national standard that limits exhaust gas [58]. Despite such improvements in the quality of diesel and gasoline, $\mathrm{PM}_{10}$ emissions are expected to rise slightly from 2010 to 2020-largely due to a growing demand for privately owned cars. In the LUP scheme of Lianyungang, the urban population would rise from 2.4 million to 2.86 million, whereas the rural population would decline from 2.6 million to 2.34 million. It is expected that population growth would bring about more vehicle use especially the small cars and mini vehicles since they are preferred in cities and towns. Despite fuel improvement, the rapid increase of the two vehicle types will lead to increasing $\mathrm{SO}_{2}$ and $\mathrm{PM}_{10}$ emissions to some extent (Table 2). Therefore, special attention should be given to optimizing the gasoline consumption of the two vehicle types and restricting their numbers.

The $\mathrm{SO}_{2}$ and $\mathrm{PM}_{10}$ concentration maps in the reference and target years (Figure 3) highlight that the majority of key plots with very high emissions are mostly located in populated urban areas. Despite its low source intensity per cell (pixel), agricultural land makes a significant contribution to 
the emissions because it covers the largest portion of the study area. Except for point sources (key plots), transportation land—which forms a road network of the entire city—has the highest source intensities of the two pollutants in 2010 and 2020. This suggests that transportation land is one of the largest pollution sources in Lianyungang.

\subsection{Spatial Characteristics of Airborne Pollutant Concentration}

An industry-based environmental impact assessment considers the impact of every single project with detailed pollutant emissions [59-61]. Many of the models employed in environmental impact assessment simulating or predicting airborne pollutant require a variety of parameters and are run on an hourly or daily basis [62-64]. The high cost of data acquisition and calculation inevitably increase the difficulty of LUPEA due to the large geographic area, with numerous plants and a large variety of environmental indicators. As land-use planning is an annually based strategy to arrange the future land use, we consider it appropriate to employ the land-use-based emission inventory method and LAPMD model to assess the LUP impact of the atmospheric environment. In addition, this methodology also facilitates the calculation of the annual concentration of airborne pollutants at a low cost. It is an improvement in LUP impact assessment on the atmospheric environment, compared with our previous study in which the environmental friendliness of a Chinese county's LUP was assessed only using the pollutant concentration in the reference year [26]. Moreover, the environmental friendliness of urban and rural residential land planning was obtained through an overlay analysis of the emission concentration maps and the urban and rural land planning map (Table 4).

Table 4. Distribution of the SO2 and PM10 concentrations in the newly planned urban and rural land by 2020 in the LUP scheme.

\begin{tabular}{|c|c|c|c|c|c|c|c|c|c|c|}
\hline \multirow{2}{*}{$\begin{array}{c}\text { Land } \\
\text { Scheme }\end{array}$} & \multirow{2}{*}{$\begin{array}{c}\text { Value } \\
\left(\mathrm{mg} / \mathrm{m}^{3}\right)\end{array}$} & \multicolumn{4}{|c|}{ Area $\left(\mathrm{hm}^{2}\right)$} & \multirow{3}{*}{$\begin{array}{c}\text { Value } \\
\mathbf{( m g / \mathbf { m } ^ { 3 } )} \\
<0.005\end{array}$} & \multicolumn{4}{|c|}{ Area $\left(\mathrm{hm}^{2}\right)$} \\
\hline & & \multicolumn{2}{|c|}{$\mathrm{SO}_{2}$ in 2010} & \multicolumn{2}{|c|}{$\mathrm{SO}_{2}$ in 2020} & & \multicolumn{2}{|c|}{$\mathrm{PM}_{10}$ in 2010} & \multicolumn{2}{|c|}{$\mathrm{PM}_{10}$ in 2020} \\
\hline \multirow{4}{*}{$\begin{array}{l}\text { Newly } \\
\text { planned } \\
\text { rural land }\end{array}$} & $<0.005$ & 1103.24 & $96.63 \%$ & 1098.55 & $96.22 \%$ & & 1132.93 & $99.23 \%$ & 1139.31 & $99.79 \%$ \\
\hline & $0.01-0.02$ & 3.78 & $0.33 \%$ & 4.19 & 0.37 & $0.02-0.04$ & 0.00 & $0.00 \%$ & 0.00 & $0.00 \%$ \\
\hline & $0.02-0.06$ & 0 & $0.00 \%$ & 3.78 & 0.33 & $0.04-0.07$ & 0.00 & $0.00 \%$ & 0.00 & $0.00 \%$ \\
\hline & $0.06-0.1$ & 0 & $0.00 \%$ & 2.33 & 0.20 & $0.07-0.14$ & 0.00 & $0.00 \%$ & 0.00 & $0.00 \%$ \\
\hline \multirow{6}{*}{$\begin{array}{l}\text { Newly } \\
\text { planned } \\
\text { urban land }\end{array}$} & $<0.005$ & $10,599.37$ & $80.67 \%$ & 9123.03 & $69.43 \%$ & $<0.005$ & $12,876.68$ & $98.00 \%$ & $13,083.84$ & $99.57 \%$ \\
\hline & $0.005-0.01$ & 2255.27 & $17.16 \%$ & 3223.11 & $24.53 \%$ & 0.005-0.02 & 247.46 & $1.88 \%$ & 56.12 & $0.43 \%$ \\
\hline & $0.01-0.02$ & 199 & $1.51 \%$ & 688.26 & $5.24 \%$ & $0.02-0.04$ & 15.81 & $0.12 \%$ & 0.00 & $0.00 \%$ \\
\hline & $0.02-0.06$ & 82.04 & $0.62 \%$ & 100.6 & $0.77 \%$ & $0.04-0.07$ & 0.00 & $0.00 \%$ & 0.00 & $0.00 \%$ \\
\hline & $0.06-0.1$ & 2.18 & $0.02 \%$ & 1.83 & $0.01 \%$ & $0.07-0.14$ & 0.00 & $0.00 \%$ & 0.00 & $0.00 \%$ \\
\hline & $>0.1$ & 2.11 & $0.02 \%$ & 3.12 & $0.02 \%$ & $>0.14$ & 0.00 & $0.00 \%$ & 0.00 & $0.00 \%$ \\
\hline
\end{tabular}

The decreases in $\mathrm{SO}_{2}$ concentration from 0.97 to 0.48 and in $\mathrm{PM}_{10}$ concentration from 1.68 to $1.15 \times 10^{-3} \mathrm{mg} / \mathrm{m}^{3}$ (Table 3) in 2010 and 2020 demonstrate that the impact of LUP on the atmosphere is expected to lessen, which is also proven by the shrinking areas of the highest concentration levels for both $\mathrm{SO}_{2}$ and $\mathrm{PM}_{10}$ from 2010 to 2020. We consider that such a weakening impact is a result of the implementation of the land-use planning in Lianyungang. Considering the maximum concentration threshold for the second level in the AQSC, the area with $\mathrm{PM}_{10}$ concentrations over $0.07 \mathrm{mg} / \mathrm{m}^{3}$ would decrease more than the area with $\mathrm{SO}_{2}$ concentrations over $0.06 \mathrm{mg} / \mathrm{m}^{3}$ (Figure 4 , Table 3). In fact, the rapid urbanization in Lianyungang will lead to population aggregation in the city center, contributing to higher airborne emissions by means of heating, cooking, and running vehicles (especially small cars and mini vehicles). Otherwise, the air pollution will be expected to decrease more than predicted, owing to the environmental measures in land-use planning.

\subsection{Evaluating the Environmental Friendliness of LUP}

The concentration maps are also useful in evaluating the environmental friendliness of LUP. By overlaying the concentration maps with the vector data representing the newly planned urban 
and rural land in GIS, we obtained the affected area at different levels (Table 4). As most of the newly planned rural land $(>95 \%)$ has very low $\mathrm{SO}_{2}$ and $\mathrm{PM}_{10}$ concentrations $\left(<0.005 \mathrm{mg} / \mathrm{m}^{3}\right)$. it is understood that that the overall impact of the layout of new rural residential land is environmentally friendly. A small part of that newly planned urban land with $\mathrm{SO}_{2}$ concentrations $<0.005 \mathrm{mg} / \mathrm{m}^{3}$ in $2020(69.43 \%)$ reveals noticeable differences in emissions from urban land and rural land, with the former releasing more $\mathrm{SO}_{2}$. The overlay analysis also reveals that all the area has $\mathrm{PM}_{10}$ concentrations $<0.04 \mathrm{mg} / \mathrm{m}^{3}$ both in 2010 and 2020 and that the $\mathrm{PM}_{10}$ pollution would have little negative influence on the newly planned residential land. In examining the newly planned urban and rural lands, we note that the new urban residential land will be more affected by air pollution than new rural residential land, and that specific efforts are therefore needed to control emissions for these two types of newly planned land.

\section{Conclusions}

Land use can increase the emissions of airborne pollutants into the atmosphere and degrade environmental quality; it is, therefore, essential to consider the impact on the atmospheric environment during land-use planning. In this study, we proposed a methodology combining the land-use-based emission inventories of airborne pollutants and the LAPMD model to assess the land-use planning atmospheric impact. Land-use-based emission inventories prove effective and feasible in collecting the overall pollutant emissions at a low cost when compared with the industrially based method, and a moderate spatial resolution is appropriate to a city-scale LUPEA. Through the land-use-based emission inventories, the LAPMD model allows a characterization of the spatial variability directly reflecting the impact of the LUP on the atmosphere. The environmental friendliness of LUP can also be assessed by overlaying the concentration maps with the newly planned urban and rural land map.

In the case study of Lianyungang, some land-use types such as urban residential and transportation land are related to higher emissions. The overall decreases in average $\mathrm{SO}_{2}$ and $\mathrm{PM}_{10}$ concentrations from the reference year of 2010 to the target year of 2020 suggest that improved atmospheric quality would be expected thanks to the implementation of land-use planning. High concentrations are mostly distributed in the city center and around key plots. There is, therefore, a concern that urban population in the affected areas will be exposed to high pollution concentrations. Although the overlay analysis reveals that the layout of newly planned urban and rural lands is environmentally friendly, emission reduction measures should be in place for the newly planned urban lands located in the areas of high $\mathrm{SO}_{2}$ and $\mathrm{PM}_{10}$ concentrations $\left(>0.005 \mathrm{mg} / \mathrm{m}^{3}\right)$.

The methodology proposed in this study highlights the assessment of the land-use planning impact on the atmosphere from a land-use point of view. It promises a low cost of data acquisition and investigation and is applicable to other areas for which data availability is restricted and, in the case of similar dispersion, to the studies which focus on airborne pollutants such as $\mathrm{NOx}$ and $\mathrm{PM}_{2.5}$. Moreover, by means of the correlation of the exploration of $\mathrm{PM}_{10}$ and $\mathrm{PM}_{2.5}$ found in other studies, it is possible to assess $\mathrm{PM}_{2.5}$ based on the $\mathrm{PM}_{10}$ data. Findings from this study are helpful for decision making if land-use planning schemes specify the objectives of airborne pollutant concentration explicitly.

Author Contributions: Conceptualization, L.C. (Longgao Chen); data curation, X.Y.; formal analysis, L.C. (Longqian Chen); investigation, X.Y.; methodology, L.C. (Longgao Chen), L.L., X.Y., and Y.Z.; software, Y.Z.; supervision, L.C. (Longqian Chen); writing-original draft, L.C. (Longgao Chen); writing-review and editing, L.L., X.M.

Funding: The project "Building the Dynamic Plinth Model for the Assessment of the Land Use Planning Environmental Impact Based on Scenario Simulation" (No.: 41601087) supported by the National Natural Science Foundation of China (NSFC) and the project "Study on the Model of Land Use Planning Environmental Multi-Temporal States Assessment at County Level" (No.: 41271121) supported by NSFC; The Research Base on the Characteristic Town-village Construction and Land Management; The project funded by the Priority Academic Program Development of Jiangsu Higher Education Institutions (PAPD).

Acknowledgments: We thank the prefectural and district governments of Lianyungang and the International Scientific Data Service Platform of the Chinese Academy of Sciences for providing the data required for the study.

Conflicts of Interest: The authors declare no conflict of interest. 


\section{Appendix A}

Table A1. Full forms and description of the acronyms.

\begin{tabular}{llll}
\hline Acronym & Full Form & Description & Reference(s) \\
\hline LUP & Land-use planning & $\begin{array}{l}\text { The process for the spatio-temporal arrangement and } \\
\text { allocation of land recourses in accordance with the } \\
\text { principles of sustainable land-use. }\end{array}$ & $\begin{array}{l}\text { T. Tang, Zhu, \& Xu, } \\
\text { (2007) [7]; Z. Tang, Bright, } \\
\text { \& Brody, (2009) [8] }\end{array}$ \\
\hline SEA & $\begin{array}{l}\text { Strategic Environmental } \\
\text { Assessment }\end{array}$ & $\begin{array}{l}\text { The process for evaluating the environmental } \\
\text { consequences of proposed policy, plan or } \\
\text { programme (PPP) and its alternatives in order to } \\
\text { ensure they are fully considered and appropriately } \\
\text { addressed at the earliest suitable stage of the } \\
\text { decision-making process. }\end{array}$ & Chen et al., (2014) [44] \\
\hline LUPEA & $\begin{array}{l}\text { Land-use planning } \\
\text { environmental impact } \\
\text { assessment }\end{array}$ & $\begin{array}{l}\text { The application of SEA in LUP is known as LUPEA. } \\
\text { It is a process for assessing the environmental impact } \\
\text { of LUP including before, during and after the } \\
\text { implementation. }\end{array}$ & $\begin{array}{l}\text { Chen, Yang, Chen, \& Li, } \\
\text { (2015) [9]; Chen et al., } \\
\text { (2014) [44] }\end{array}$ \\
\hline \multirow{2}{*}{ LAPMD } & $\begin{array}{l}\text { Long-term air pollution } \\
\text { multi-source dispersion } \\
\text { model }\end{array}$ & $\begin{array}{l}\text { A model to spatially estimate the annual } \\
\text { concentration of atmospheric pollutants, it was } \\
\text { established based on the Gaussian diffusion model. }\end{array}$ & $\begin{array}{l}\text { Chen, Yang, \& Kang, } \\
\text { (2012) [26] }\end{array}$ \\
\hline
\end{tabular}

\section{References}

1. Wu, S.; Mickley, L.J.; Kaplan, J.O.; Jacob, D.J. Impacts of changes in land use and land cover on atmospheric chemistry and air quality over the 21st century. Atmos. Chem. Phys. Discuss. 2011, 11, 15469-15495. [CrossRef]

2. Murphy, L.U.; O'Sullivan, A.; Cochrane, T.A. Quantifying the spatial variability of airborne pollutants to stormwater runoff in different land-use catchments. Water. Air. Soil Pollut. 2014, 225, 2016. [CrossRef]

3. Heald, C.L.; Spracklen, D.V. Land use change impacts on air quality and climate. Chem. Rev. 2015, 115, 4476-4496. [CrossRef]

4. Shahraki, N.; Turkay, M. Analysis of interaction among land use, transportation network and air pollution using stochastic nonlinear programming. Int. J. Environ. Sci. Technol. 2014, 11, 2201-2216. [CrossRef]

5. Chester, M.V.; Nahlik, M.J.; Fraser, A.M.; Kimball, M.A.; Garikapati, V.M. Integrating life-cycle environmental and economic assessment with transportation and land use planning. Environ. Sci. Technol. 2013, 47, 12020-12028. [CrossRef]

6. Chen, L.L.; Li, L.; Yang, X.; Zheng, J.; Chen, L.L.; Shen, Z.; Kervyn, M. A worst-case scenario based methodology to assess the environmental impact of land use planning. Habitat Int. 2017, 67, 148-163. [CrossRef]

7. Tang, T.; Zhu, T.; Xu, H. Integrating environment into land-use planning through strategic environmental assessment in China: Towards legal frameworks and operational procedures. Environ. Impact Assess. Rev. 2007, 27, 243-265.

8. Tang, Z.; Bright, E.; Brody, S. Evaluating California local land use plan's environmental impact reports. Environ. Impact Assess. Rev. 2009, 29, 96-106. [CrossRef]

9. Chen, L.; Yang, X.; Chen, L.; Li, L. Impact assessment of land use planning driving forces on environment. Environ. Impact Assess. Rev. 2015, 55, 126-135. [CrossRef]

10. Zhou, Y.; Cheng, S.; Li, J.; Lang, J.; Li, L.; Chen, D. A new statistical modeling and optimization framework for establishing high-resolution PM10 emission inventory-II. Integrated air quality simulation and optimization for performance improvement. Atmos. Environ. 2012, 60, 623-631. [CrossRef]

11. Zhao, H.; Tong, D.Q.; Gao, C.; Wang, G. Effect of dramatic land use change on gaseous pollutant emissions from biomass burning in Northeastern China. Atmos. Res. 2015, 153, 429-436. [CrossRef]

12. Kota, S.H.; Zhang, H.; Chen, G.; Schade, G.W.; Ying, Q. Evaluation of on-road vehicle CO and NOx national emission inventories using an urban-scale source-oriented air quality model. Atmos. Environ. 2014, 85, 99-108. [CrossRef] 
13. Napelenok, S.L.; Foley, K.M.; Kang, D.; Mathur, R.; Pierce, T.; Rao, S.T. Dynamic evaluation of regional air quality model's response to emission reductions in the presence of uncertain emission inventories. Atmos. Environ. 2011, 45, 4091-4098. [CrossRef]

14. Sadavarte, P.; Venkataraman, C. Trends in multi-pollutant emissions from a technology-linked inventory for India: I. Industry and transport sectors. Atmos. Environ. 2014, 99, 353-364. [CrossRef]

15. Pandey, A.; Sadavarte, P.; Rao, A.B.; Venkataraman, C. Trends in multi-pollutant emissions from a technologylinked inventory for India: II. Residential, agricultural and informal industry sectors. Atmos. Environ. 2014, 99, 341-352. [CrossRef]

16. Varela, Z.; Aboal, J.R.; Carballeira, A.; Real, C.; Fernández, J.A. Use of a moss biomonitoring method to compile emission inventories for small-scale industries. J. Hazard. Mater. 2014, 275, 72-78. [CrossRef] [PubMed]

17. Pope, A.; Ndoh, T.; Chappell, L. Analysis of Multi-Pollutant Emissions Inventories for Key Industrial Sectors. Available online: https://www3.epa.gov/ttnchie1/conference/ei18/session9/pope_pres.pdf (accessed on 9 January 2019).

18. Dons, E.; Van Poppel, M.; Kochan, B.; Wets, G.; Int Panis, L. Modeling temporal and spatial variability of traffic-related air pollution: Hourly land use regression models for black carbon. Atmos. Environ. 2013, 74, 237-246. [CrossRef]

19. Beelen, R.; Voogt, M.; Duyzer, J.; Zandveld, P.; Hoek, G. Comparison of the performances of land use regression modelling and dispersion modelling in estimating small-scale variations in long-term air pollution concentrations in a Dutch urban area. Atmos. Environ. 2010, 44, 4614-4621. [CrossRef]

20. Montagne, D.; Hoek, G.; Nieuwenhuijsen, M.; Lanki, T.; Pennanen, A.; Portella, M.; Meliefste, K.; Eeftens, M.; Yli-Tuomi, T.; Cirach, M.; et al. Agreement of land use regression models with personal exposure measurements of particulate matter and nitrogen oxides air pollution. Environ. Sci. Technol. 2013, 47, 8523-8531. [CrossRef]

21. Hoek, G.; Beelen, R.; de Hoogh, K.; Vienneau, D.; Gulliver, J.; Fischer, P.; Briggs, D. A review of land-use regression models to assess spatial variation of outdoor air pollution. Atmos. Environ. 2008, 42, 7561-7578. [CrossRef]

22. Mölter, A.; Lindley, S.; de Vocht, F.; Simpson, A.; Agius, R. Modelling air pollution for epidemiologic research-Part II: Predicting temporal variation through land use regression. Sci. Total Environ. 2010, 409, 211-217. [CrossRef] [PubMed]

23. Carvalho, A.C.; Carvalho, A.; Gelpi, I.; Barreiro, M.; Borrego, C.; Miranda, A.I.; Pérez-Muñuzuri, V. Influence of topography and land use on pollutants dispersion in the Atlantic coast of Iberian Peninsula. Atmos. Environ. 2006, 40, 3969-3982. [CrossRef]

24. Corburn, J. Urban land use, air toxics and public health: Assessing hazardous exposures at the neighborhood scale. Environ. Impact Assess. Rev. 2007, 27, 145-160. [CrossRef]

25. Berchet, A.; Zink, K.; Muller, C.; Oettl, D.; Brunner, J.; Emmenegger, L.; Brunner, D. A cost-effective method for simulating city-wide air flow and pollutant dispersion at building resolving scale. Atmos. Environ. 2017, 158, 181-196. [CrossRef]

26. Chen, L.; Yang, X.; Kang, J. A case study of land use planning environmental assessment based on the air pollution analysis. In Advances in Computational Environment Science; Springer: Berlin/Heidelberg, Germany, 2012; pp. 319-328.

27. Xing, Y.; Brimblecombe, P. Dispersion of traffic derived air pollutants into urban parks. Sci. Total Environ. 2018, 622-623, 576-583. [CrossRef]

28. Wang, L.; Li, P.; Yu, S.; Mehmood, K.; Li, Z.; Chang, S.; Liu, W.; Rosenfeld, D.; Flagan, R.C.; Seinfeld, J.H. Predicted impact of thermal power generation emission control measures in the Beijing-Tianjin-Hebei region on air pollution over Beijing, China. Sci. Rep. 2018, 8, 934. [CrossRef] [PubMed]

29. Zhang, Y.X.; Shao, M.; Zhang, Y.H.; Zeng, L.M.; He, L.Y.; Zhu, B.; Wei, Y.J.; Zhu, X.L. Source profiles of particulate organic matters emitted from cereal straw burnings. J. Environ. Sci. 2007, 19, 167-175. [CrossRef]

30. Li, L.J.; Wang, Y.; Zhang, Q.; Li, J.X.; Yang, X.G.; Jin, J. Wheat straw burning and its associated impacts on Beijing air quality. Sci. China, Ser. D Earth Sci. 2008, 51, 403-414. [CrossRef]

31. Kong, S.; Bai, Z.; Lu, B. Comparative analysis on emission factors of carbonaceous components in PM2.5 and PM10 from domestic fuels combustion. China Environ. Sci. 2014, 34, 2749-2756. 
32. Zhu, J.; Wang, T.; Deng, J.; Jiang, A.; Liu, D. An emission inventory of air pollutants from crop residue burning in Yangtze River Delta Region and its application in simulation of a heavy haze weather process. Acta Sci. Circumstantiae 2012, 32, 3045-3055.

33. He, L.; Hu, J.; Xie, S.; Song, J.; Zu, L. $\mathrm{CH}_{4}$ and $\mathrm{N}_{2} \mathrm{O}$ emission inventory for motor vehicles in China in 2010. Res. Environ. Sci. 2014, 27, 28-35.

34. Cai, H.; Xie, S. Determination of emission factors from motor vehicles under different emission standards in China. Acta Sci. Nat. Univ. Pekin. 2010, 46, 319-326.

35. Breivik, K.; Sweetman, A.; Pacyna, J.M.; Jones, K.C. Towards a global historical emission inventory for selected PCB congeners-A mass balance approach: 2. Emissions. Sci. Total Environ. 2002, 290, 199-224. [CrossRef]

36. Zhang, H.; Ye, X.; Cheng, T.; Chen, J.; Yang, X.; Wang, L.; Zhang, R. A laboratory study of agricultural crop residue combustion in China: Emission factors and emission inventory. Atmos. Environ. 2008, 42, 8432-8441. [CrossRef]

37. Yang, X.; Li, L.; Chen, L.; Chen, L.; Shen, Z. Improving ASTER GDEM Accuracy Using Land Use-Based Linear Regression Methods: A Case Study of Lianyungang, East China. ISPRS Int. J. Geo-Inf. 2018, 7, 145. [CrossRef]

38. Xie, Y.; Wang, Y.; Zhang, K.; Dong, W.; Lv, B.; Bai, Y. Daily Estimation of Ground-Level PM 2.5 Concentrations over Beijing Using 3 km Resolution MODIS AOD. Environ. Sci. Technol. 2015, 49, 12280-12288. [CrossRef]

39. Huang, G.; Cheng, T.; Zhang, R.; Tao, J.; Leng, C.; Zhang, Y.; Zha, S.; Zhang, D.; Li, X.; Xu, C. Optical properties and chemical composition of PM2.5 in Shanghai in the spring of 2012. Particuology 2014, 13, 52-59. [CrossRef]

40. De Hoogh, K.; Héritier, H.; Stafoggia, M.; Künzli, N.; Kloog, I. Modelling daily PM2.5 concentrations at high spatio-temporal resolution across Switzerland. Environ. Pollut. 2018, 233, 1147-1154. [CrossRef]

41. Wang, E. PM2.5 Will Be Monitored in All City-Level Regions as of 2015. Available online: http:/ / business. sohu.com/20141231/n407436335.shtml (accessed on 20 December 2015).

42. Zhao, C.X.; Wang, Y.Q.; Wang, Y.J.; Zhang, H.L.; Zhao, B.Q. Temporal and spatial distribution of PM 2.5 and PM10 pollution status and the correlation of particulate matters and meteorological factors during winter and spring in Beijing. Huan Jing Ke Xue 2014, 35, 418-427.

43. Pan, Y.; Li, N.; Zheng, J.; Yin, S.; Li, C.; Yang, J.; Zhong, L.; Chen, D.; Deng, S. Emission inventory and characteristics of anthropogenic air pollutant sources in Guangdong Province. Acta Sci. Circumstantiae 2015, 35, 2655-2669.

44. Chen, L.; Yang, X.; Chen, L.; Potter, R.; Li, Y. A state-impact-state methodology for assessing environmental impact in land use planning. Environ. Impact Assess. Rev. 2014, 46, 1-12. [CrossRef]

45. Ministry of Environmental Protection of the People's Republic of China; State Administration for Market Regulation. Ambient Air Quality Standard in China (GB 3095-2012). Available online: http:/ /img.jingbian. gov.cn/upload/CMSjingbian/201806/201806210853050.pdf (accessed on 9 January 2019).

46. Statistics Department of Lianyungang. 2011 Statistical Yearbook of Lianyungang. Available online: http: / / www.lyg.gov.cn/zglygzfmhwz/tjnj/content/993f4531-2093-4df0-8df7-f422b62d1395.html (accessed on 9 January 2019).

47. Lo, J.C.F.; Lau, A.K.H.; Fung, J.C.H.; Chen, F. Investigation of enhanced cross-city transport and trapping of air pollutants by coastal and urban land-sea breeze circulations. J. Geophys. Res. Atmos. 2006, 111. [CrossRef]

48. Indumati, S.; Oza, R.B.; Mayya, Y.S.; Puranik, V.D.; Kushwaha, H.S. Dispersion of pollutants over land-water-land interface: Study using CALPUFF model. Atmos. Environ. 2009, 43, 473-478. [CrossRef]

49. Lam, J.S.L.; Lau, A.K.H.; Fung, J.C.H. Application of refined land-use categories for high resolution mesoscale atmospheric modelling. Bound.-Layer Meteorol. 2006, 119, 263-288. [CrossRef]

50. Polkowska, Ż.; Górecki, T.; Namieśnik, J. Determination of atmospheric pollutants in wet deposition. Environ. Rev. 2011, 19, 185-213. [CrossRef]

51. Lee, B.S.; Chiou, C.B. The use of CFC-12, CFC-11 and $\mathrm{CH} 3 \mathrm{CCl} 3$ to trace terrestrial airborne pollutant transport by land-sea breezes. Atmos. Environ. 2007, 41, 3360-3372. [CrossRef]

52. Kahyaoğlu-Koračin, J.; Bassett, S.D.; Mouat, D.A.; Gertler, A.W. Application of a scenario-based modeling system to evaluate the air quality impacts of future growth. Atmos. Environ. 2009, 43, 1021-1028. [CrossRef]

53. Zheng, S.; Zhou, X.; Singh, R.P.; Wu, Y.; Ye, Y.; Wu, C. The spatiotemporal distribution of air pollutants and their relationship with land-use patterns in Hangzhou City, China. Atmosphere 2017, 8, 110. [CrossRef] 
54. Liang, S.; Lei, J.; Zhang, A. Temporal and spatial distribution of PM2.5 concentration in Beijing-Tianjin-Hebei region and its correlation with PM10 and five air quality indicators. Jiangsu Sci. Technol. Inf. 2018, 35, 40-45.

55. Li, Y.; Chen, Q.; Zhao, H.; Wang, L.; Tao, R. Variations in PM10, PM2.5and PM1.0 in an urban area of the Sichuan basin and their relation to meteorological factors. Atmosphere 2015, 6, 150-163. [CrossRef]

56. Gehrig, R.; Buchmann, B. Characterising seasonal variations and spatial distribution of ambient PM10 and PM2.5 concentrations based on long-term Swiss monitoring data. Atmos. Environ. 2003, 37, 2571-2580. [CrossRef]

57. Koçak, M.; Mihalopoulos, N.; Tutsak, E.; Theodosi, C.; Zarmpas, P.; Kalegeri, P. PM10 and PM2.5 composition over the Central Black Sea: Origin and seasonal variability. Environ. Sci. Pollut. Res. 2015, 22, 18076-18092. [CrossRef]

58. Ministry of Environmental Protection of the People's Republic of China. Limits and Measurement Methods for Exhaust Pollutants from Compression Ignition and Gas Fuelled Positive Ignition Engines of Vehicles (III IV V) (GB 17691-2005); China Environmental Science Press: Beijing, China, 2005.

59. Židoniene, S.; Kruopiene, J. Life Cycle Assessment in environmental impact assessments of industrial projects: Towards the improvement. J. Clean. Prod. 2015, 106, 533-540. [CrossRef]

60. Roes, A.L.; Patel, M.K. Environmental assessment of a sugar cane bagasse food tray produced by roots biopack-results of a shortcut-life cycle assessment. J. Biobased Mater. Bioenergy 2011, 5, 140-152. [CrossRef]

61. Lilic, N.; Cvjetic, A.; Knezevic, D.; Milisavljevic, V.; Pantelic, U.; Lilic, N.; Cvjetic, A.; Knezevic, D.; Milisavljevic, V.; Pantelic, U. Dust and Noise Environmental Impact Assessment and Control in Serbian Mining Practice. Minerals 2018, 8, 34. [CrossRef]

62. Tsegas, G.; Moussiopoulos, N.; Barmpas, F.; Akylas, V.; Douros, I. An integrated numerical methodology for describing multiscale interactions on atmospheric flow and pollutant dispersion in the urban atmospheric boundary layer. J. Wind Eng. Ind. Aerodyn. 2015, 144, 191-201. [CrossRef]

63. Pokhrel, R.; Lee, H. Estimation of air pollution from the $\{\mathrm{OGVs}\}$ and its dispersion in a coastal area. Ocean Eng. 2015, 101, 275-284. [CrossRef]

64. Jiang, W.; Hu, F.; Wang, W. A non-hydrostatic dispersion modeling system and its application to air pollution assessments over coastal complex terrain. J. Wind Eng. Ind. Aerodyn. 2000, 87, 15-43. [CrossRef]

(C) 2019 by the authors. Licensee MDPI, Basel, Switzerland. This article is an open access article distributed under the terms and conditions of the Creative Commons Attribution (CC BY) license (http:/ / creativecommons.org/licenses/by/4.0/). 